\title{
Stability assessment of the chemical composition of the water used to supply the circuits in selected power plants of TAURON Group
}

\author{
Marcin Karpiński ${ }^{1, *}$, Kajetan d'Obyrn ${ }^{1}$, Ewa Kmiecik, and Barbara Tomaszewska ${ }^{1}$ \\ ${ }^{1}$ AGH University of Science and Technology, Faculty of Geology, Geophysics and Environmental \\ Protection, Al. Mickiewicza 30, 30-059 Kraków, Poland
}

\begin{abstract}
Electricity production in Poland is carried out mainly in conventional power plants, and the necessary resources include fuel and water. Significant water intake and production of sewage necessitate the application of technological solutions limiting the negative impact on the water environment. For this reason, Tauron Group's power plants for replenishing losses in cooling circuits use beside surface water, water from inactive mining plants. Due to the increased content of chlorides and sulphates in relation to surface water, mine water show significant corrosion properties. However, they are characterized by a relatively stable chemical composition mainly dependent on the physicochemical properties of the geological environment. The surface water quality is affected by many factors, such as seasons, thaws, rainfall, or the presence of pollutants from sewage disposal. The relative stability of the chemical composition of mine water allows for easier determination of chemical dosage during treatment process. The paper presents a stability assessment of the chemical composition of waters used to supplement circuits based on data from 2007-2017.
\end{abstract}

\section{Introduction}

Electricity production in Poland is carried out mainly in conventional power and heating plants fired with coal or lignite. Energy production in a thermal power plants is carried out using a three-stage process of transformation, and the necessary resource to obtain it are fuel and water. Due to the constantly decreasing availability of water sources for industry, including for the needs of the power plant, the problem of water protection is becoming more and more important. Modern plants operate in accordance with the principle of sustainable development in the manner that is least detrimental to the natural environment [1]. Despite this, energy production in thermal power plants involves a use of significant amounts of water. It is estimated that every kilowatt-hour $(\mathrm{kWh})$ of electricity produced requires the withdrawal of approximately $0.1 \mathrm{~m}^{3}$ of water [2].

\footnotetext{
*Corresponding author: karpinski@agh.edu.pl
} 
Cooling is the most water-intensive process in conventional energy production. Simultaneously, due to the relatively low quality requirements for raw water, mine waters can be used to supplement losses in the cooling circuits. Such solutions are successfully used i.a. in power plants located in the Lusatian mining region [3].

In the summer of 2003 and 2006 many power units in European plants had to work with limited power due to water shortages and high temperatures caused by hot and dry summer season [3]. A similar situation took place in 2015. The hydrological drought in Poland was so severe for conventional energy production that the energy system operator introduced restrictions in the supply and consumption of electricity. According to the forecasts of climatologists, the frequency of periods of drought will increase in the coming years both in Europe and other parts of the world. Conventional power plants, especially with open cooling circuits, will be forced to find alternative sources of water supply $[3,4]$.

Natural waters are not suitable for direct use for energy purposes. Effects caused by poor water quality usually appear after a long period of time, causing a decrease in the durability of devices with a simultaneous deterioration of their efficiency. Therefore, the water to supplement losses in the water circuits of the power plant must be free of chemicals causing scale on heated surfaces and should be non-corrosive towards the materials from which the circuit is made. Due to high purity criteria that must be met by water introduced to technological processes, electricity production plants have their own water treatment plants $[5,6]$.

\section{Jaworzno III Power Plant water management}

The Jaworzno III Power Plant is part of the TAURON Wytwarzanie S.A. and is located in south-western part of Jaworzno. It consists of two power plants: Power Plant II and Power Plant III. The Power Plant III is equipped with six power units with a total electrical output of 1345 MWe. The Power Plant III has three power units, and it is also a municipal heat and power plant. Its electric output is $190 \mathrm{MWe}$, while the maximum thermal capacity is $320 \mathrm{MWt}$ [7].

\subsection{Water supply}

There are three main water circuits in the power plant: water/steam circuit (boiler circuit), cooling circuit and district heating circuit. The purpose of the water circulating in the cooling circuit is to receive heat contained in the superheated steam and condense it before returning it to the boiler. A closed cooling circuit was used in both plants. After reaching a certain degree of condensation of circulating water, a part of it is removed in the form of a blowdown and replenished with treated water [8].

Water consumption for replenish circuits in conventional power plants ranges from 1.7 to $8.0 \mathrm{~m}^{3} / \mathrm{MWe}$ [9]. The majority of this is used in cooling processes. The demand for water to supplement losses in the cooling circuit at Power Plant III amounts to approx. $16200000 \mathrm{~m}^{3} /$ year [10]. This water is taken from the intake located in the town of Sosnowiec at $2.025 \mathrm{~km}$ of the Biała Przemsza river. Then, raw water is pumped ca. $5 \mathrm{~km}$ through pipelines to the area of Power Plant III [11]. In order to reduce costs and negative environmental impact, Power Plant II for the production of cooling water mainly uses mine water supplied from the closed down Jan Kanty Hard Coal Mine held by Central Department of Mine Dewatering and in case of interruptions in pumping mine water surface water from the Biała Przemsza river in a total amount of $4600000 \mathrm{~m}^{3} /$ year [10]. The Jan Kanty mine maintains a stationary dewatering system, and the inflow of mine water amounts to ca. $30 \mathrm{~m}^{3} / \mathrm{min}$ [12]. Part of the pumped water (about $10 \mathrm{~m}^{3} / \mathrm{min}$ ) flows through the mine water canal to the preliminary settlers located in the mine water pumping station, and its excess is discharged to 
river at $19.150 \mathrm{~km}$ of the Przemsza river. Raw water, after passing through settling tanks, is pumped through pipelines to the Power Plant II located ca. $2.5 \mathrm{~km}$ away [13].

\subsection{Cooling water treatment}

The required cooling water quality depends on the cooling system. Generally, the water temperature should be as low as possible, also treated water should be stable and noncorrosive towards metals and non-metallic materials from which the cooling circuit devices are made. Cooling water should not contain suspensions, oils, iron and manganese compounds as well as excessive amounts of dissolved solids. In addition, it must be free of chemicals causing scaling on heated surfaces $[14,15]$.

Water for cooling purposes is prepared in accelerators. In the processes of coagulation and decarbonisation, it is brought to the state of carbonate calcium equilibrium, which reduces the aggressive properties of water and prevents the precipitation of calcium carbonate [15].

Raw water from the Jan Kanty Mine drainage is characterized by mineralization and the content of chlorides and sulphates, which is higher than surface water. The presence of these ions increases the corrosive nature of water to metals and concrete. The process of decarbonisation does not lead to a reduction in the concentration of chlorides or sulphates, therefore the water in the cooling circuit of Power Plant II reaches the permitted level of condensation faster than the water in the cooling circuit in the Power Plant III. Due to the higher mineralization and increased concentration of chlorides and sulphates in the raw mine water, the cooling circuit of Power Plant II requires more frequent refreshing.

\section{Methodology}

The testing of mine and surface water chemical composition was carried out on a monthly basis in the period between 2007-2017 in accordance with the internal quality system procedures (PN-EN ISO 5667-13: 2004). Samples were collected without fixing by employees of the power plant from pipelines located at the Biała Przemsza river water intake and at the mine water pumping station. The water was analysed by the Central Laboratory of the Chemical Analyses Department of TAURON Wytwarzanie (PCA accreditation No. AB 688) [16]. A maximum of 17 parameters were determined in the samples, while this paper concerns ions whose increased concentration is typical for mine water: sulphate $\left(\mathrm{SO}_{4}{ }^{2-}\right)$ and chloride $\left(\mathrm{Cl}^{-}\right)$ions as well as $\mathrm{pH}$ and electrical conductivity (EC). Sulphates concentration was determined by turbidimetry method and chlorides concentration by Mohr method (PN-ISO 9297: 1994). The $\mathrm{pH}$ and EC values were measured by potentiometric (PNEN ISO 10523: 2012) and conductometric (PN-EN 27888: 1999) methods respectively.

\section{Data analysis}

In order to evaluate the stability of the chemical composition of raw waters, the results of 124 mine water analyses and results of 132 surface water analyses from 2007-2017 were used. Due to internal reasons in March and April 2014 as well as August, October, November and December 2016 the power plant did not use mine water and its composition was not analysed. Assessment of trends was performed using GWSDAT software [17]. Trend analysis was performed using nonparametric method - local linear regression. Methodology is presented e.g. in [18]. Table 1 presents basic descriptive statistics for the entire data set. 
Table 1. Basic descriptive statistics for the $\mathrm{EC}, \mathrm{pH}$, chloride and sulphate ions concentration in mining water $(\mathrm{M})$ and river water $(\mathrm{R})$.

\begin{tabular}{|c|c|c|c|c|c|c|c|c|}
\hline \multirow{2}{*}{$\begin{array}{c}\text { The value of } \\
\text { statistics }\end{array}$} & \multicolumn{2}{|c|}{$\begin{array}{c}\mathbf{E C} \\
{[\boldsymbol{\mu S} / \mathbf{c m}]}\end{array}$} & \multicolumn{2}{c|}{$\begin{array}{c}\mathbf{p H} \\
{[-]}\end{array}$} & \multicolumn{2}{c|}{$\begin{array}{c}\text { Chlorides } \\
{[\mathbf{m g} / \mathbf{l}]}\end{array}$} & \multicolumn{2}{c|}{$\begin{array}{c}\text { Sulphates } \\
{[\mathbf{m g} / \mathbf{I}]}\end{array}$} \\
\cline { 2 - 9 } & $\mathbf{M}$ & $\mathbf{R}$ & $\mathbf{M}$ & $\mathbf{R}$ & $\mathbf{M}$ & $\mathbf{R}$ & $\mathbf{M}$ & $\mathbf{R}$ \\
\hline Mean & 1353 & 912 & 7.53 & 7.96 & 142.1 & 54.1 & 379.9 & 218.7 \\
\hline Min. & 1173 & 740 & 7.08 & 7.30 & 128.0 & 33.2 & 297.0 & 161.0 \\
\hline Max. & 1444 & 1231 & 8.07 & 8.24 & 156.2 & 90.8 & 464.0 & 484.0 \\
\hline Std. deviation & 39 & 81 & 0.20 & 0.16 & 4.2 & 10.2 & 41.9 & 31.8 \\
\hline Range & 271 & 491 & 0.99 & 0.94 & 28.2 & 57.6 & 167.0 & 323.0 \\
\hline
\end{tabular}

The temperature of mine water is about $11^{\circ} \mathrm{C}$ and the temperature of river water ranges from 0 to $25^{\circ} \mathrm{C}$ depending on the season and ambient temperature. According to internal procedures, water temperature was not measured for the needs of analyses $[11,13]$.

The analysis of sequence plots for EC (Fig. 1), pH (Fig. 2) and chloride ion concentration (Fig. 3) in raw mine water shows that there are no statistically significant monotonic trends. It means that raw mine water is characterized by stable chemical composition in respect of these parameters. The analysis of sequence plots for sulphate ion concentration (Fig. 4) shows that there is a statistically significant downward trend. This is related to changes in the intensity of dissolution in the mine water of oxidized sulphur compounds from mine workings. In the coming years, their further reduction should take place, which will result in a decrease in the concentration of sulphates in the water pumped from this mine [19,20,21]. As a result of the chemical weathering of sulphide minerals, there is also a strong acidification of waters flowing through the excavations, resulting in $\mathrm{pH}$ changes (Fig. 2). $\mathrm{pH}$ values are reduced in relation to waters pumped from similar depths from the neighbouring active Sobieski hard coal mine, where sulphide oxidation processes are not so intense. Closure of mines and mineral weathering processes do not affect significantly on the changes in chlorides concentration. Their high content is associated with a vertical hydrogeochemical zoning.

The analysis of sequence plots for EC (Fig. 1), pH (Fig. 2) and chloride ion concentrations (Fig. 3) in raw water from Biała Przemsza river shows statistically significant downward trends. The analysis of sequence plots for sulphate ion concentration (Fig. 4) shows that there are no statistically significant monotonous trends. It means that river water have a relatively less stable chemical composition in the respect of analysed parameters. Water from Biała Przemsza river is characterized by better chemical parameters than mine water. It exhibit less electrical conductivity as well as chloride and sulphate content. However, the values of electrical conductivity and chlorides concentration measured in surface water have a larger range than analogous results for mine water. Its chemical composition is depends on a number of factors, e.g. current season, thawing, rainfall or presence of contamination from wastewater. Rainwater and snowmelt change the chemical composition and increase the content of suspended solids [14]. In recent years there has been a deterioration in the quality of water in the Biała Przemsza river. 

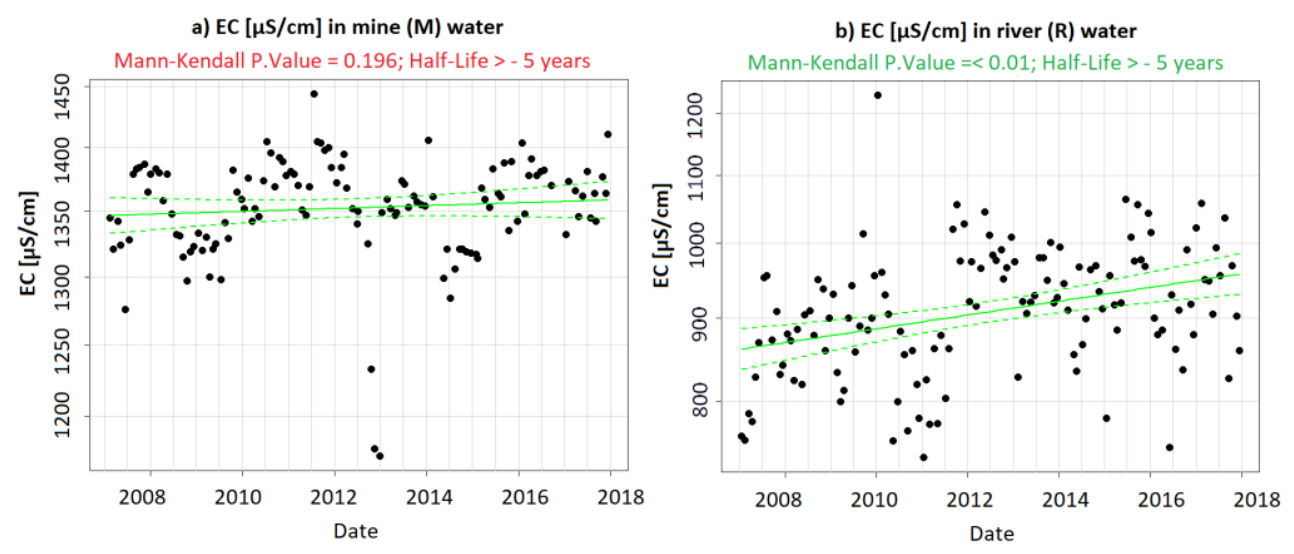

Fig. 1. Conductivity changes in a) mine (M) water b) river (R) water in 2007-2017.
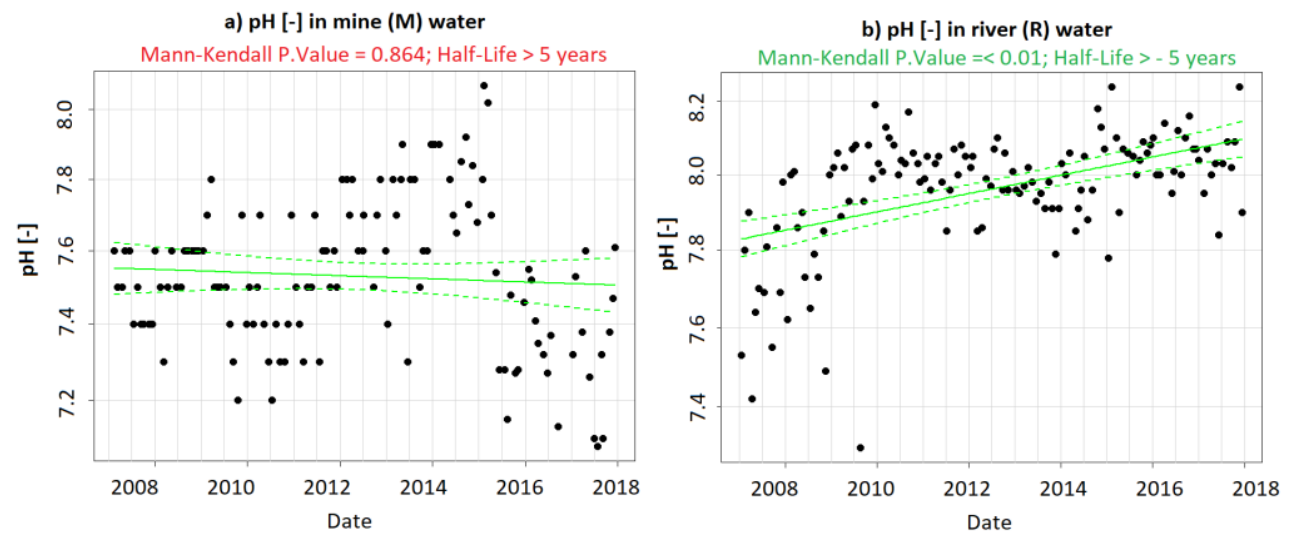

Fig. 2. pH changes in a) mine (M) water b) river (R) water in 2007-2017.
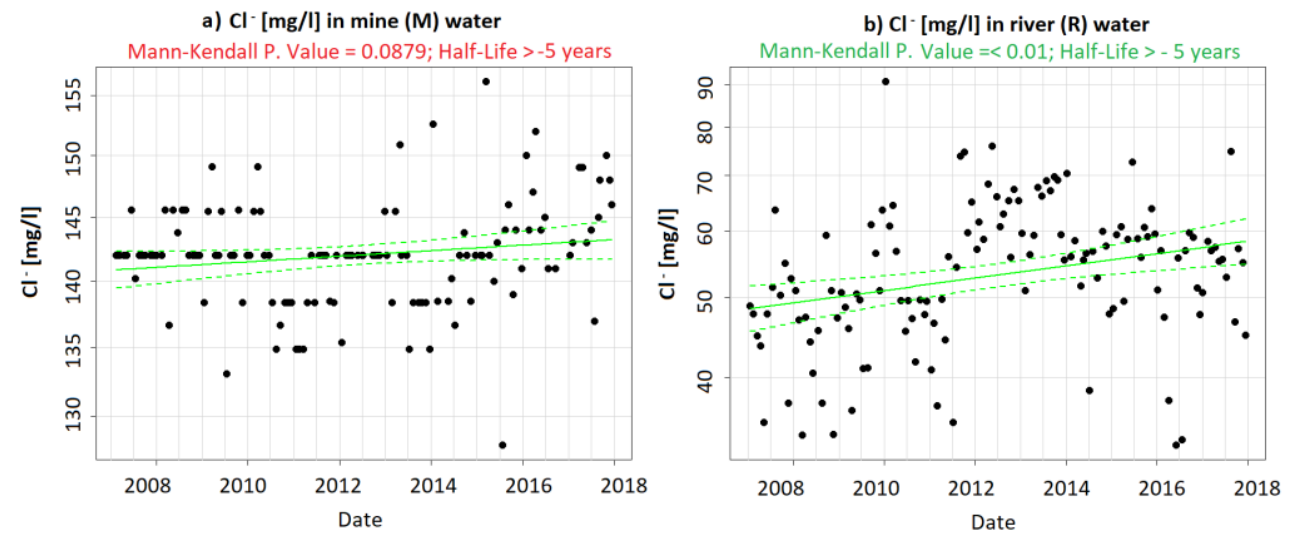

Fig. 3. Fluctuation of chlorides concentration in a) mine (M) water b) river (R) water in 2007-2017. 

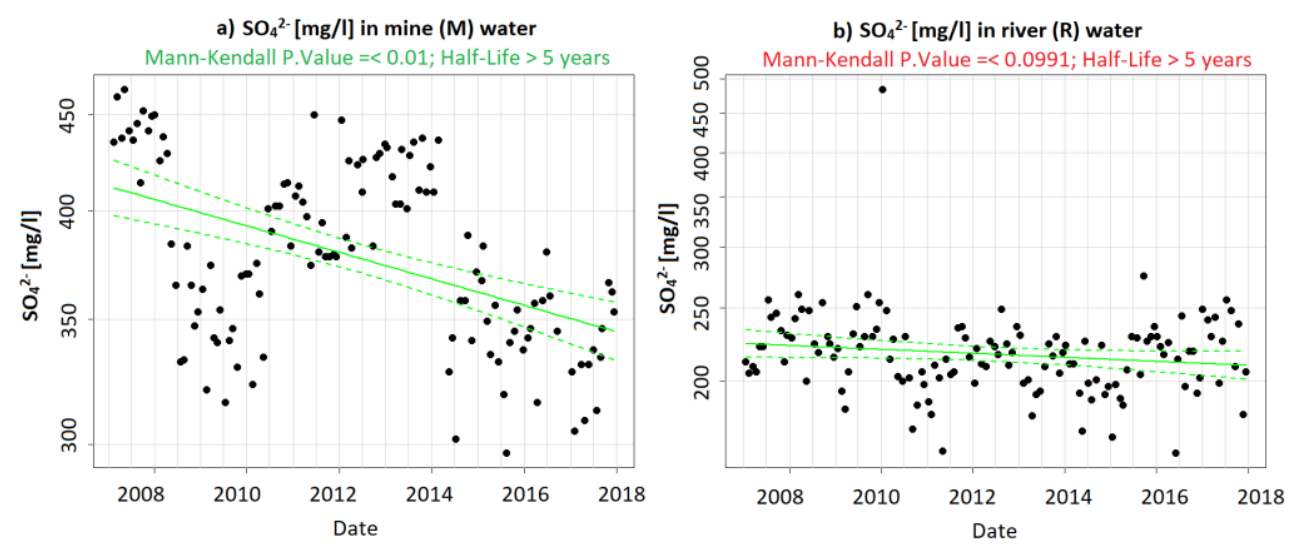

Fig. 4. Fluctuation of sulphate concentration in a) mine (M) water b) river (R) water in 2007-2017.

\section{Summary}

Due to the significant pollution and drainage of the soil-water environment caused by the presence of heavy industry [22] and mining activity, power plants located in the Silesia Voivodship must in particular seek solutions to reduce water consumption in plants [23, 24]. One of the ways to protect surface water resources may be the usage of water from dewatering mines by conventional power plants. It can be used to supplement losses in circulations with lower quality requirements.

This paper presents the assessment of stability of chemical composition of mine and surface water used at the Jaworzno III Power Plant. The analysis was carried out for chlorides and sulphates concentration as well as electrical conductivity and $\mathrm{pH}$. Based on the analyses carried out, no significant changes in the quality ( $\mathrm{EC}, \mathrm{pH}$, chloride concentration) of mine water were found over time. Changes in the sulphate concentration are related to the reduction of pyrite oxidation processes. Chemical composition of surface water is relatively less stable. Despite the increased content of chlorides and sulphates in mine water, its stability of the chemical composition facilitates the determination of the dose of chemicals used in the treatment process and its better control.

Mine water typically shows increased chloride and sulphate concentrations as compared to surface water. Therefore, they also show considerable corrosive activity. At the same time, they have relatively stable chemical composition depending mainly on the physical and chemical properties of the geological location. Its chemical composition is not affected by a number of factors which are of importance for surface water, e.g. current season, thawing, rainfall or presence of contamination from wastewater.

Better chemical parameters make a surface water is a better source of cooling water. Due to rational water management and environmental protection, mine water can be a viable alternative [25].

Mine water, compared to surface water, can provide much better stability of the inflow to the intakes due to high retention in post-mining voids. It is also possible to change the level of the water table in closed down and dewatered mines in the case of rare seasonal fluctuations in the inflow to the pumping station.

The authors would like to thank branch managers Małgorzata Sztyrak and Mirosław Żbik (TAURON Wytwarzanie S.A.) for providing data for the purposes of this paper. The paper has been prepared under the AGH-UST statutory research grant No. 11.11.140.797 and 11.11.140.031. 


\section{References}

1. D. Sąkol-Sikora, Energet. Ciepl. i Zaw. 9 (2011)

2. T. J. Feeley, T. J. Skone, G. J. Stiegel Jr, A. McNemara, M. Nemeth, B. Schimmoller, J. T. Murphy, L. Manfredo Energy J. 33, 1, 1 (2008)

3. H. Koch, S. Vögele, Ecol. Econ. 68, 7, 2031 (2009)

4. W. Lise, J. Laan, Energy Sustain. Dev. 28, 10 (2015)

5. D. Sąkol-Sikora, Joint Meeting of Water Management Councils of the Water Regions: Little Vistula and Upper Oder and the Presidencies of the Standing Committee for the Participation of the Society Conf. Proc. Toszek (2009)

6. J. R. Rak, B. Kucharski, Environ. Prot. Eng. 35, 2, 15 (2009)

7. http://www.tauron-wytwarzanie.pl/oddzialy/jaworznoiii/Strony/opis.aspx (20.01.2018)

8. Operating Instruction of turbogenerators (in polish: Instrukcja eksploatacyjna turbogeneratorów), Nr CKI 2005/320/Er (mat. TAURON)

9. T. Jamrocha, VIII Discussion Forum Diagnostics and chemistry for power industry Conf. Proc. Szczyrk, 161 (2011)

10. Jaworzno III Power Plant - Water budget (2016) (mat. TAURON)

11. Operating instructions for the water pumping station on the Biała Przemsza River, (in polish: Instrukcja eksploatacji ujęcia i pompowni wody na rzece Biała Przemsza), $\mathrm{Nr}$ CKI 2013/1344/Er (mat. TAURON)

12. A. Czapnik, A. Jasińska, E. Janson, Biul. Państw. Inst. Geol. 436, 55 (2009)

13. Operating instructions for wastewater treatment plant and pumping station in Power Plant III, (in polish: Instrukcja eksploatacji oczyszczalni ścieków technologicznych oraz pompowni nadbrzeżnej w Elektrowni III), Nr CKI 2016/1812/Er (mat. TAURON)

14. E. Sierakowski, J. Mrożek, Control of water and steam in power industry (in polish: Kontrola wody i pary w energetyce), Wyd. Energopom. Elektr. (1998)

15. Operating instructions for decarbonisation and water coagulation stations (in polish: Instrukcja eksploatacji instalacji dekarbonizacji i koagulacji wody), Nr CKI 2005/295/Er (mat. TAURON)

16. http://www.pca.gov.pl/akredytowane-podmioty/akredytacje-aktywne/laboratoriabadawcze/AB\%20688,plik.html (20.01.2018)

17. W. Jones, M. Pence, Ground Water Spatio-Temporal Data Analysis Tool (GWSDAT Version 2.0 User Manual), Shell Global Solution (2013)

18. E. Kmiecik, S. Stefaniak, J. Szczepańska, I. Twardowska, Proc. Of Spie. 5586, 126 (2004)

19. P. Bukowski, I. Augustyniak, SGEM2013 Conf. Proc. 2, 25 (2013)

20. R. J. Bowell. IMWA Symp Proc, 2, 75 (2004)

21. K. Labus, S. Skoczynska, Geol. Q 57, 3, 561 (2013)

22. T. Suponik, Environ. Prot. Eng. 41, 1, 15 (2015)

23. K. Niedbalska, P. Bukowski, J. Kubica, A. Haładus, K. Kura, SGEM2016 Conf. Proc. 1, 707 (2016)

24. P. Bukowski, A. Haładus, E. Krogulec, SGEM2016 Conf. Proc. 1, 1021 (2016)

25. M. Karpiński, E. Kmiecik, E3S Web Conf. 22, 00077 (2017) 